\title{
Does the rise of China present a threat to the interests of the United States?
}

\section{Apakah kebangkitan China memberikan ancaman terhadap kepentingan Amerika Serikat?}

\author{
Fadhila Inas Pratiwi', Dini Putri Saraswati ${ }^{2}$, M. Muttaqien ${ }^{3}$ \\ ${ }^{1}$ Faculty of Social and Political Science, Universitas Airlangga, Indonesia \\ ${ }^{2}$ Faculty of Arts, University of Groningen, Netherlands \\ ${ }^{3}$ Department of International Relations, Faculty of Social and Political Science, Universitas \\ Airlangga, Indonesia \\ E-mail: m.muttaqien@fisip.unair.ac.id
}

\begin{abstract}
The rise of China can be perceived either as a threat or as an opportunity to and for the US, mostly depending on US grand foreign policy interests and its related strategies. If the US feels comfortable living in a multipolar world in which it is considered to be an equal among the major powers, China is more likely to be perceived as a partner. However, if the goal of US foreign policy is to strengthen its position as the sole superpower or even as a hyper-power, and does not choose to recognise other major countries, then the rise of China will be perceived as a threat. Based on this underlying assumption, this article seeks to examine the exact interests of the US: Is it threatened by the rise of China or is it not? This article starts by explaining the grand theories and relating it to the research question. The next explanation examines the economic ties between the two countries. The final consideration is the possibility of military conflict given several recent occurrences, such as the Taiwan and South China Sea (SCS) dispute. This article concludes that the rise of China will threaten the interests of the US. However, it will not necessarily lead to war between them.
\end{abstract}

Keywords: China's rise; US interest; US-China relations; realism; neo-liberalism

\begin{abstract}
Abstrak
Bangkitnya Cina bisa dipersepsikan sebagai ancaman atau kesempatan bagi Amerika Serikat (AS) yang mana hal ini tergantung pada kepentingan kebijakan luar negeri dan strategi yang dilakukan oleh AS. Apabila AS merasa nyaman berada dalam multi-polar world order yang mana kekuatan antar negara besar dianggap sama, maka China lebih bisa dipersepsikan sebagai sekutu, namun apabila tujuan dari kebijakan luar negeri AS untuk memperkuat posisi sebagai satu-satunya negara adikuasa bahkan hyper-power, maka kebangkitan Cina akan dipersepsikan sebagai ancaman. Berdasarkan asumsi ini, artikel ini berusaha menganalisis kepentingan AS yang tepat: Apakah akan terancam oleh kebangkitan Cina atau kebangkitan Cina belum tentu mengancam AS?. Penjelasan artikel ini dimulai dengan penjabaran teori besar dan menghubungkannya dengan studi kasus Cina dan AS. Penjelasan berikutnya yaitu analisis mengenai hubungan ekonomi antara dua negara. Kemudian, analisis terakhir yaitu kemungkinan adanya konflik militer yang dapat dilihat dari kasus terbaru yaitu Taiwan dan konflik Laut China Selatan untuk menentukan apakah kebangkitan Cina akan mengancam kepentingan AS. Kesimpulan dari artikel ini yaitu bahwa kebangkitan Cina memang menjadi ancaman bagi AS, namun, hal ini tidak mengarah pada konflik peperangan antar dua negara tersebut.
\end{abstract}

Kata kunci: China's rise; US interest; US-China relations; realism; neo-liberalism

\section{Introduction}

The rise of China in relation to the US can be perceived as a threat or as an opportunity depending on US grand foreign policy interests and its related strategies. If the US feels comfortable living in a multi-polar world in which it is considered to be an equal among the major powers, China is more likely to be perceived as a partner. However, if the goal of US foreign policy is to strengthen its position as the sole superpower or even as a hyper-power, and does not choose to recognise other major countries, then the rise of China will be perceived as a threat (Wang 2009:295). Based on this underlying assumption, this essay seeks to examine the exact interests of the US: Is it threatened by the rise of China or is it not necessarily threatened by the rise of China? The next explanation 
continues by examining the economic ties between the two countries. The final consideration is the possibility of military conflict given recent events, such as the Taiwan and South China Sea (SCS) disputes, in order to determine whether or not China's rise will threaten US interests.

\section{Research Method}

This research used the literature review method by analysing, comparing and contrasting arguments and building from the entirety of the argument using related resources. The author used secondary resources such as books, journal articles, the Internet, informative media and research reports.

\section{Result and Discussion}

\section{US interest and grand theories}

There are at least two main interests regarding US foreign policy. The first interest is to maintain the global rules and norms, such as in liberal international economic systems. This is based on the theory of an open market for trade and investment, which brings in benefits not only for the US but also for the rest of the world. The second interest is to maintain a global military presence, regional stability and the security of US alliances such those with Japan, South Korea, Australia and others (Goodman 2013:3-4, Glaser 2012). Given this interest, is it true that China's rise presents a threat to the interests of the United States? In answering this question, there are two theories used to explain these relations. The first theory, realism, argues that the international system is in an anarchic condition where the great powers feel threatened by each other's existence and where they tend to compete in order to be the dominant player. This makes them feel safer in that way. This propensity could lead to conflict and war. Therefore, from this perspective, China's rise can be seen as something dangerous to the United States, as the dominant power right now. The existence of multiple great powers means that they will try to compete and eliminate one another. Different from the first theory, the second theory, which is neo-liberal, argues that China is already integrated into a peaceful world system through economic and diplomatic engagement. This is also supported by Chinese leaders, who state that China is on the road to peaceful development and not threatening anyone. In this sense, this refers to the United States (Xie \& Page 2010:481).

These two perspectives have different standpoints regarding state relations. The realist argument can also be differentiated into two; defensive and offensive realism. Defensive realism sees that nationstates try to avoid power gaps with other states, however, it is unnecessary that they will maximise their power for their own sake (Donnelly in Burchill et al 2005:43). On the other hand, offensive realism, as Mearsheimer suggests, is where "states seek to survive under anarchy by maximising their power", which results in institutions being unable to influence this kind of behaviour. In contrast, institutionalists argue that institutions are capable of bringing peace, although it will weaken their power (Mearsheimer 1995:82). Furthermore, the rise of economic integration means that the tendency to resort to conflict and war will be diminished since the involved states will have a common interest in trade and economics. They will try to empower and strengthen one another. Potential state collaboration in an anarchical situation for liberal institutionalists is much better than what neorealists assume. Institutions in this sense are capable of influencing a state's behaviour in specific policy areas, for example, the Law of the Sea. The state's uncertain behaviour could be minimised since the existence of institutions prompts the regularity pattern of the state's behaviour. In addition, economic interdependence is proven to be in line with the decreasing of territorial occupation. The advantage of trade and cooperation between states is higher compared to military competition and territorial control (Burchill in Burchill et al 2005:64-65).

\section{US-Chinese economic aspect}

The worries about China are focused on China's economic rise. China's GDP annual growth rate was around 9.76 per cent from 1989 until 2016 (Trading Economics 2017). If China's economy continues to grow at the same rate for two more decades, then it will become a rival and even surpass the United States. On the other hand, it also can be argued that China's GDP is still smaller than Americas. It 
may take 50 years for China to overtake America's GDP and replace it as the world leader (The Atlantic 2015). However, China already has a massive economic influence in Asia (Art 2010:359). China's rise has made it the number one target of foreign direct investment in the region and in the world, and this has caused US exports to decline in the region. The US export's decline can lead to the assumption that China is gaining leverage over its neighbours at the US's economic expense (Christensen 2006:105).

This parallels with one of the branches of realist theory, offensive realism, which argues that if China continues to grow economically then it will attempt to dominate Asia in the way that the US dominates the Western Hemisphere (Clark 2011:19, Mearsheimer 2014:1, He 2017:134). At some point, it is true that China will dominate Asia, particularly in economics. In 2009, China possessed more than 50 per cent of the total regional trade and became the largest trade partner in the Asian region (Das 2013:217). Seeing this situation, President Barack Obama put his economic policy strategy at the centre of the Asia-Pacific region and altered his trade policy to "pivot" towards Asia. He launched the Trans-Pacific Partnership (TPP) negotiations to broaden liberalisation ties with eleven other Asia-Pacific members such as Brunei, Chile, New Zealand, Singapore, Australia, Peru, Vietnam, Malaysia, Canada, Mexico, and Japan. In a sense, this move will provide an economic benefit to the US and strengthen American leadership in the region, thereby counterbalancing China's strong regional influence in Asia (Goodman 2013:7-9). America would not have directed its policy pivot toward Asia if the US did not see China as a threat to their economic presence in the region.

On the other hand, under neo-liberal assumptions, it can be argued that China's rise is within the Western-oriented system that is the product of US leadership, so it is not necessarily a threat to US interests (Zhou 2008:134). In fact, the more that China needs strong, prosperous partners around the world, the more important that the Chinese economy will be a threat to the US and the rest of the world (Eikenberry 2015:2). Furthermore, there are deep economic ties between the US and China. China's growth is heavily dependent on foreign direct investment and technology from the US, which is also China's largest export market. In turn, China's exports give US consumers and firms access to inexpensive goods and materials (Jones 2007:21-22). China is currently the US's second-largest merchandise trading partner, its third-largest export market and its biggest source of imports (Morrison 2017:4-7). Therefore, as both states are intertwined with each other because of trade and investment relations, this tends to prevent the potentiality of conflict and maintains the peaceful situation. Likewise, because of the high level of economic interdependence, an attempt to destroy one another also means destroying themselves (Wang 2009:311, Art 2010:363).

China has evolved inside the US economic system such as by joining the International Monetary System (IMF), World Bank and World Trade Organisation (WTO), which reflects a world economic order dominated by the US and Western countries (Ikenberry 2008:29-33). However, China has also used this system to bring them benefits and interests. The establishment of the Asian Infrastructure Investment Bank (AIIB), which is led by China without US involvement, can be a tool to increase China's influence in the region. The Asian Development Bank (ADB), as a part of the World Bank, is an institution in which the US and Japan are the main players. Both institutions have the same role, which is focused on taking part in financing Asian infrastructure and development projects. The risk arising from the existence of these two institutions would be the creation of two blocks of economic influence in Asia: one led by China and the other led by the US and Japan. In addition, through the establishment of AIIB, China can accelerate its own trade arrangements, resulting in concern as to whether the US is still able to maintain its economic rules, norms, and systems in the region (Subacchi 2015). This situation can be related to defensive realism logic. It can be assumed that China tries to balance itself with the US in terms of economic sphere of influence, since each state is trying to minimise the power gap between them. Nonetheless, it unnecessarily makes them have bad relations and provokes them into eliminating one another as part of the offensive realist argument.

\section{US-Chinese military aspect}

In military terms, the US interest is to maintain a global presence and regional stability, which can be connected to support US global economic activities and the security of US allies. To some degree, there is a possibility that China will counter US military forces, because Chinese economic power can 
help to finance a fast-paced military modernization program (Christensen 2006:96). This scenario is also supported by the fact that Chinese military spending always increases year to year. For instance, in 2017, China's military budget was around $\$ 147.9$ billion, which was a seven per cent increase from the 2016 budget of $\$ 146.6$ billion. Meanwhile, in 2015, the budget stood at $\$ 144.2$ billion (Center for Strategic \& International Studies 2017). However, this spending is much lower than the military spending of the United States. Before stepping down as the president, Barack Obama proposed \$582.7 billion for the defence budget in 2017 (Department of Defence 2016). In addition, in 2012, the United States was responsible for 39 per cent of the world's total military expenditure, which was then followed by China's 9.5 per cent. This means that US military spending alone is almost four times more than China's military spending (Global Issues 2012). Therefore, US military capabilities remain far more advanced and powerful compared to China. China does not necessarily threaten the US military presence in the region, since US military forces are already globally deployed, technologically advanced and have massive concentrations of firepower all around the Chinese rim (Nathan \& Scobell 2012:37).

Nevertheless, a threat to US interests can be seen in the Taiwan and South China Sea (SCS) cases where military conflict between the two countries is likely to happen (Mearsheimer 2014:5). The US wants stability in the Taiwan Strait and desires a peaceful resolution to resolve Taiwan's status. While on China's side, it is part of their core national interest to reunify with Taiwan and they will use military force if Taiwan attempts to declare its independence (Glaser 2011:5). This is surely a threat to the US, because if the US tries to deter China from using force to solve the Taiwan issue, the result would be that the PRC will weary of Taiwanese independence. Therefore, it will cause Beijing to further intensify its military efforts around Taiwan's territory (Art 2010:375, Friedberg 2005:29). The other option would be that the United States could consider backing away from its commitment to Taiwan, removing the most visible and contentious flashpoint between them (Glaser 2011:6). However, this cannot be done because it ties in to the credibility of the US commitments in other East Asia countries, such as Japan. If the US failed to defend Taiwan from China's attack, it would also threaten Japan, as one of the US's main allies in the region (Friedberg 2005:23).

However, the Taiwan case does not necessarily need to become a battlefield between China and the United States, as offensive realists have argued, because America can do several things to avoid this from happening. First, they could make it clear to Beijing that they do not have any hidden agendas and no interest in seeing the separation of the Chinese mainland and Taiwan (Wang 2009:325, Art 2010:375). Second, the US military deterrence needs to remain strong in the Taiwan Strait in order to prevent any military attack from China while also restraining Taiwan from taking steps that China would interpret as moving toward independence (Art 2010:376). It can be assumed that the US should accommodate China's interest in Taiwan by preventing Taiwan from declaring its independence. Maintaining a strong military deterrence position within Taiwanese territory will protect US interests, defend Taiwan from China's attacks and strengthen the potentiality of peaceful resolutions.

The second case involves the South China Sea (SCS) dispute, in which China has claimed almost the entire region. Right now, China is in an ongoing disputes with Vietnam over control of the Paracel Islands and with Brunei, Malaysia, Philippines, Taiwan, and Vietnam over the Spratly Islands (both islands are in the South China Sea) (Mearsheimer 2014:6). Today, China regularly performs military air patrols over the disputed islands, along with building artificial land, airstrips, and other militarily useful infrastructures - thus claiming a 200-mile EEZ (Exclusive Economic Zone) around them. The United States will not accept these particular Chinese activities because it will threaten several US interests in the region, such as the freedom of navigation and commercial shipping, and a peaceful resolution to the ownership of the disputed territory (Gompert et al. 2016: 4). Furthermore, China's aggressive behaviour can also be seen when they routinely intercept U.S. reconnaissance flights. This escalates the possibilities of an accident. For example, the crash between a U.S. EP-3 reconnaissance plane and a Chinese F-8 fighter jet near Hainan Island in 2001. This kind of situation will affect the high state of tension and escalation between the states and trigger a major political crisis (Glaser 2012). 
Although China poses a threat to US interests in the South China Sea case, right now, a war between the two countries is still unlikely because both countries have nuclear deterrence to prevent military conflict from happening. Nuclear weapons are a major force for peace simply because they are weapons of mass destruction and they work to dramatically lower the possibility of war by either miscalculation or deliberate decision (Art 2010:372). As has already been mentioned before, with the economic interdependence and global integration of the US and Chinese economies, a Sino-US war could be immensely costly for both parties, East Asia, and the world. China relies on international trade in general and relies on exports to the United States. Likewise, the US relies on imports and direct investments in China. These vulnerabilities are a major reason as to why war is so unlikely to happen between them (Gompert et al. 2016:41).

From the explanation of US-Chinese economic and military aspects, it can be said that it is true that China's rise could threaten the interests of the US since that it will reduce the domination of the US in the world political constellation. Nevertheless, it can be argued that China's rise unnecessarily brings out conflict with the US. There is the notion of China's peaceful rise becoming something interesting that is to be further explored. From the cases above, it can be seen that deterring US is not the main agenda for China since it will be counter effective to the Chinese ambition to rise peacefully. Moreover, China tends to be open within the international trading system and "could not afford to antagonise Washington" (Council on Foreign Relations 2006). The case of Taiwan and the South China Sea cannot be solely seen as China's general behaviour when trying to have a conflicting relationship with the US. In addition, under China's peaceful rise, the Chinese government has enacted various policies in order to reduce the threat assumption from other states toward China. These steps include building cooperation with second-tier powers such as EU, Russia, and India, as well as expanding and enhancing trade with the states in the Asia-Pacific region. Last but not least, continuing to pursue cooperation clearly states that China has no intention to conflict with the US (Xia 2007).

\section{The promise of China's peaceful rise}

Both the US and China are actively engaged with the international community. Especially for the US, active participation in international organisations plays an important role in their foreign policy. Sanford (1999) showed that the US makes up one quarter of the international organisations that were established by international agreements. As a hegemonic power, the role of the US is the key consideration in the international community. For example, certain cases related to peace, conflict and foreign intervention issues are followed by issues related to human rights or nuclear weapons, which when situated in the Middle East, has taken the US vote into account (Wang 1999). Stverkova (2017) argued that a dominant power like the US tends to see the advantages of international organisations as being able to produce a more stable and predictable international environment and to capture other states in order to map a desirable policy orientation. On the contrary, the dominant authority often loses their own policy autonomy and it has to minimise its ability to exercise power.

In terms of their involvement in international organisations, China has a different approach to the US. China is rather slow to engage with international institutions, as the UN just recognised China as the sole legitimate representative of the country in 1971, which marked China's reintegration into the international community. Moreover, there was a time where China had not joined the World Bank and IMF until after the death of Mao Zedong in September 1976. "By the turn of the century, however, its growing participation in international organisations has provided both a source and measure of its expanding power" (Kent 2002). In 2000, China became a member of more than 2,000 international organisations. Even though China's leaders have found that its membership in international organisations has extended China's power and promoted its participation in globalisation and modernisation, they are also conscious of the constraints that follow international citizenship, especially the possible impact on China's growth rate and the threats posed by economic interdependence for North-South relations. Therefore, in some cases, China would rather use bilateral mechanisms for the resolution of interstate conflict due to their involvement in a big international community (Kent 2002).

Due to the aftermath of World War I, some scholars believe that international institutions could be an effective tool to resolve international disputes. Woodrow Wilson underlined that "international 
organisation and international law could be an independent force for peace and justice as well as a counterweight to the perceived negative effects of the traditional international system" (Sanford 1999). In fact, power politics and traditional diplomacy are seen to be escalating conflicts, as they tend to use the realism approach to resolve conflict, while international organisations are more liberal. International communities use public opinion as the instrument to resolve disputes as well as objective mediation mechanisms. Thus, in a collective security system, the approach from international organisations can possibly enforce world peace. Moreover, international organisations can also assist countries in identifying and solving functional problems that they hold in common on a more prosaic level (Sanford 1999). In the case of the contestation of power between the US and China, it can be said that by involving certain international organisations, they are actually restraining themselves from exacerbating the conflict based on the above-mentioned arguments. International organisations can propose a more liberal approach to resolve any conflict. Although the involvement of China in international organisations is considered to be new, China has never intended to show political influence in these communities. In fact, China tries to hold back its aggressiveness in relation to its participation in the international organisations. For instance, in the case of the military intervention in Libya by NATO, China abstained. Therefore, we do not see any excuses for the US to perceive China's rise as a threat because of this peaceful engagement of China to certain international organisations, especially as China's cooperation in the international organisations is seen of as exercising soft power through trade and foreign aid.

\section{Conclusion}

China's rise in power will always present a threat to US interests since every major world power seeks to maximise their own power. From an economic standpoint, China has the largest influence in Asian regional trade, which will decrease the US's economic presence in the region. This is why, under the Obama administration, his trade policy changed to pivot toward Asia. China also used the US international economic system to establish their investment banking system, AIIB, which will challenge the previous US-Japan led investment bank, ADB, in the region.

In military terms, although the US has a massive military power compared to China, in the Taiwan and South China Sea cases, China does pose a threat to US interests in both of these regions. Like in Taiwan for example, China has made it clear that if Taiwan declares its independence, then they will not hesitate to use military force to solve the Taiwanese problem. This will threaten US interests in relation to pursuing peaceful resolutions over Taiwan statues. This can be a threat to the US's main ally, Japan. This threat has also happened in the South China Sea case, where China has claimed almost the entire region and used its military power to preserve the South China Sea statues. It can also endanger US interests there in terms of freedom of navigation, trade, and the potentiality of peaceful resolution in the disputed region.

However, this threat will not necessarily lead to war as realism suggests. Like in the Taiwan case, the United States is able to embark on several steps to accommodate China's interests and at the same time, to secure their own interests, which can be translated into decreasing the potentiality of military conflict between them. In the South China Sea case, the possibility of war between the US and Chinese is much higher since they have already clashed before. However, the existence of a nuclear deterrence will prevent a major war from happening. In addition, because of China and the United States having deep economic interdependence, it will apply the neo-liberal thesis as well, in that both countries will tend to prefer to avoid conflict and seek to preserve peace since an attempt to destroy one another will also mean destroying themselves.

\section{References}

Art, Robert J. 2010. The United States and the Rise of China: Implications for the Long Haul. Political Science Quarterly, Vol. 125, No 3, pp. 359-391.

Burchill, Scott., Linklater, Andrew., Devetak, Richar., Donnelly, Jack., Paterson, Matthew., ReusSmit, Christian., True, Jacqui. 2005. Theories of International Relations. New York. Palgrave Macmillan. 
Center for Strategic \& International Studies. 2017. What does China really spend on its military? [online]. Available at: http://chinapower.csis.org/military-spending/. [Accessed 13/03/2017].

Christensen, Thomas J. 2006. Fostering Stability or Creating a Monster? The Rise of China and U.S. Policy toward East Asia. International Security, Vol. 31, No. 1, pp. 81-126.

Clark, Ian. 2011. China and the United States: a succession of hegemonies?. International Affairs, Vol. 87, No. 1, pp. 13-28.

Council on Foreign Relations. 2006. The Promise and Pitfalls of China's Peaceful Rise. Available at: https://www.cfr.org/backgrounder/promise-and-pitfalls-chinas-peaceful-rise. [Accessed 11/07/2018].

Das, Dilip K. 2013. The Role of China in Asia's Evolution to Global Economic Prominence, Asia \& the Pacific Policy Studies, Vol. 1, No. 1, pp. 216-229.

Eikenberry. Karl W. 2015. China's Place in U.S. Foreign Policy. The American Interest, Volume 10, Number 6 [online journal]. Available at: http://www.the-american interest.com/2015/06/09/ chinas-place-in-u-s-foreign-policy/ [Accessed 12/03/2017].

Friedberg, Aaron L. 2005. The Future of U.S.-China Relations: Is Conflict Inevitable? International Security, Vol. 30, No. 2, pp. 7-45.

Glaser, Bonnie. 2012. Armed Clash in the South China Sea [online]. Available at: http://www.cfr.org/ asia-and-pacific/armed-clash-south-china-sea/p27883. [Accessed 16/03/2017].

Glaser, Charles. 2011. Will China's Rise Lead to War?. Foreign Affairs, Vol. 90, Issue 2, pp. 80-91.

Global Issues. 2013. World Military Spending [online]. Available at: http://www.globalissues.org/ article/75/world-military-spending. [Accessed 14/03/17].

Gompert, David C., Astrid Cevallos, and Cristina L. Garafola. 2016. War with China: Thinking Through the Unthinkable. RAND Corporation.

Goodman, Matthew P. 2013. U.S. Economic Engagement in East Asia and The Pacific. Center for Strategic and International Studies.

He, Kai. 2017. Explaining United States-China relations: neoclassical realism and the nexus of threat-interest perceptions. The Pacific Review, Vol. 30, No. 2, pp. 133-151.

Ikenberry, G. John. 2008. The Rise of China and the Future of the West: Can the Liberal System Survive?. Foreign Affairs, Vol. 87, No. 1, pp. 23-37.

Jones, Alexandra. 2007. Responding to the Rise of China. Security Challenges, Vol. 3 No. 1, pp. $17-27$.

Kent, Ann. 2002. China's International Socialization: The Role of International Organizations. Global Governance, Vol. 8, No. 3, pp. 343 - 364.

Mearsheimer, John J. 1995. A Realist Reply. International Security, Vol. 20 No. 1, pp. 82-93.

Mearsheimer, John J. 2014. Can China Rise Peacefully? [online]. Available at: http://nationalinterest. org/commentary/can-china-rise-peacefully-10204. [Accessed 14/03/17].

Morrison, Wayne M. 2017. China-U.S. Trade Issues. Congressional Research Service.

Nathan, Andrew J. \& Scobell, Andrew. 2012. How China Sees America: The Sum of Beijing's Fears. Foreign Affairs, Vol. 91, No. 5, pp. 32-47.

Sanford, Jonathan E. 1999. International Organization as an Instrument of Foreign Policy. National War College.

Stverkova, Iva, Mgr. 2017. The Role of the US in NATO: How Did It Change after 9/11 under Bush Administration. Master's Thesis. Charles University, Prague. 
Subacchi, Paola. 2015. The AIIB Is a Threat to Global Economic Governance [online]. Available at: http://foreignpolicy.com/2015/03/31/the-aiib-is-a-threat-to-global-economic-governancechina/. [Accessed 16/03/17].

The Atlantic. 2015. 'The World Is Too Important to Be Left to America' [online]. Available at: https://www.theatlantic.com/international/archive/2015/06/china-dream-liu-mingfupower/394748/. [Accessed 16/03/17].

Trading Economics. 2017. China GDP Annual Growth Rate [online]. Available at: http://www. tradingeconomics.com/china/gdp-growth-annual. [Accessed 13/03/17].

Department of Defense. 2016. Department of Defense (DoD) Releases Fiscal Year 2017 President's Budget Proposal [online]. Available at: https:/www.defense.gov/News/News-Releases/ News-Release-View/Article/652687/department-of-defense-dod-releases-fiscal-year-2017presidents-budget-proposal. [Accessed 13/03/17].

Wang, Jianwei. 2003. China: A Challenge or Opportunity for the United States? Journal of East Asian Studies, Vol. 3, No. 2, pp. 293-333.

Wang, T. Y. 1999. U.S. Foreign Affairs and UN Voting: An Analysis of Important Issues. International Studies Quarterly, Vol. 43, No. 1, pp. 199-210.

Xia, Ming. 2007. "China Threat" or a "Peaceful Rise of China"? [online] Available at: https://archive. nytimes.com/www.nytimes.com/ref/college/coll-china-politics-007. [Accessed 11/07/2018].

Xie, Tao \& Page, Benjamin I. 2010. Americans and the Rise of China as a World Power. Journal of Contemporary China, Vol. 19, No. 65, pp. 479-501.

Zhou, Jinghao. 2008. Does China's Rise Threaten the United States?. Asian Perspective, Vol. 32, No. 3, pp. 171-182. 